\title{
An Effective MBA: Perspectives of Students, Faculty, and Employers
}

\author{
Sunil J. Ramlall ${ }^{1} \&$ Dhanmati Padma Ramlall ${ }^{2}$ \\ ${ }^{1}$ President and Management Consultant, Strategic HRM Consulting, LLC, USA \\ ${ }^{2}$ Accounting Faculty, Century College, Minnesota, USA \\ Correspondence: Sunil J. Ramlall, Ph.D., President and Management Consultant, Strategic HRM Consulting, LLC, \\ USA. Tel: 651-210-2761. \\ Received: June 29, 2016 \\ Accepted: August 1, 2016 \\ Online Published: August 17, 2016 \\ doi:10.5430/jms.v7n3p18 \\ URL: http://dx.doi.org/10.5430/jms.v7n3p18
}

\begin{abstract}
The demand for Master of Business Administration (MBA) education has increased tremendously over recent years. Having an MBA qualification is seen as a passport for a managerial role. The prestige of MBA education, however, has fluctuated. There have been numerous critiques of the MBA. This article examined the existing literature on perspectives of MBA faculty, MBA students, and employers on the effectiveness of MBA programs. So, from a student perspective, what are their expectations? Do their expectations get fulfilled? MBA faculty will frequently ponder if they are adequately preparing students to be leaders in organizations. Employers expect MBA graduates to excel in the workplace. In addition to the different perspectives, we offered several suggestions for greater success and satisfaction of students, faculty, and employers.
\end{abstract}

Keywords: MBA, MBA effectiveness, graduate business education

The demand for Master of Business Administration (MBA) education has increased tremendously over recent years. Having an MBA qualification is seen as a passport for a managerial role. The prestige of MBA education, however, has fluctuated. In a fast-paced global work environment, MBA graduates are often criticized for their inability to transfer content knowledge to real situations (Sulaiman \& Mohezar, 2009). This article examines the existing literature on perspectives of MBA faculty, MBA students, and employers on the effectiveness of MBA programs. So, from a student perspective, what are their expectations? Do their expectations get fulfilled? MBA faculty will frequently ponder if they are adequately preparing students to be leaders in organizations. Employers expect MBA graduates to excel in the workplace. To what extent are all of these expectations being met?

An MBA is an internationally recognized business degree. It is academic in nature and yet provides practical preparation for individuals in business and management. An MBA can not only complement professional experience, but an MBA graduate is able to command a higher salary than his or her colleague who does not have the degree (Blackburn, 2011). According to the National Center for Education Statistics, 191,571 people graduated from U.S. schools in 2012 with advanced degrees in business, representing about one in four of all master's degrees conferred nationwide (Hann, 2014) making the MBA the most popular graduate degree in the U.S. Given such popularity of the degree, how can all stakeholders ensure the highest satisfaction and effectiveness of the investment and at the same time? Are students, faculty, and employers generally satisfied with MBA programs? Through the literature review, we explore the different perspectives of the respective stakeholder groups and offer multiple recommendations given the gaps that exist.

\section{Perspectives of Students, Faculty, and Employers}

We reviewed the current literature from the perspectives of i) MBA students, ii) MBA Faculty, and iii) Employers. These perspectives enabled up to have a deeper understanding on their respective points of view. Providing a quality graduate program is a difficult and ever-changing task. To begin, the expectations of external constituents may vary widely. Educational institutions are scrutinized on the basis of the benefits that they provide to businesses, organizations, and communities through graduates (Sculley, 1988). Given this, the pursuit of the meaning of quality in education, the extant literature provides numerous suggestions (Rapert, Smith, Velliquette, \& Garretson, 2004). We explain some of these through the perspectives of the respective groups. 


\section{Students' Expectations of MBA Programs}

MBA students are often treated as a blank sheet of paper on which the MBA program and its faculty etch and imprint the knowledge and philosophy of business success. Implicit in this thinking is that students are willing neophytes in this ritualistic process without a perceptual screen shaping and molding the content being espoused by legions of business philosophers-both academic and professional (Lundstrom, 2011). The literature on MBA education is replete with studies showing enrollment trends, curriculum issues, placement, starting salaries, ranking of programs, and demographic descriptors of test takers and enrollees in MBA program (Lundstrom, 2011). While this was true in 2011, we also confirmed this to remain true even in 2014. There was little research on the deep expectations of students. Of course, there are the implied expectations of gaining employment, advancing in one's career, and higher remuneration. Additionally, a survey back in 2008 showed that self-improvement, career development, enhancing business skills, having a positive impact on society are most important to MBAs immediately after they receive their degrees (The-Aspen-Institute, 2008). Other reasons such as networking opportunities, experiencing a foreign culture (for overseas students) and increased professional and personal effectiveness are also proposed (Blackburn, 2011).

Vazquez and Ruas (2012) argue that specialized competences publicized in the portfolios of MBA program are not the same as those that are actually valued and sought after by MBA students in their educational process and business actions. There seems to be a perceived lack of an integrated vision connecting management education to corporate strategy and knowledge acquired in MBA programs should prepare managers to enhance their business actions to increase the company core competences. They claim that management education programs which were designed for corporate needs, such as MBA In-company, are a more useful and strategic option than generic MBA courses.

In furthering to answer what students expect of MBA programs, they want to be able to effectively lead teams and get along effectively with others. Over a century ago, President Theodore Roosevelt noted "the ability to get along with others" was the key to success (Bedwell, Fiore, \& Salas, 2014). In teams, interpersonal skills (IPS) have been found to account for $32 \%$ of variance in peer ratings of performance (Neuman, 1999). Some even suggest that interpersonal competence may be as important as general mental ability or task expertise (Goleman, 1998). As cited in Bedwell et al. (2014), the importance of IPS will continue to grow in all sectors of business as collaborative efforts continue to dominate the organizational landscape. "All stakeholders in MBA educational endeavors agree that interpersonal skills are critical for managerial success, yet are not adequately addressed in classrooms despite efforts to do so (Datar, 2010.; R. Rubin \& Dierdorff, 2011.)

\section{Faculty Perspectives of MBA Programs}

Central to popular critiques of the MBA is the questioning of the relationship between what is taught in MBA programs and actual management practices. Management education reports of the late 1980s, for example, suggested that MBA programs did not produce individuals who were able to perform managerial work to a satisfactory standard in practice (Constable \& McCormick, 1987 ; Porter \& McKibbin, 1988). As we know, the MBA curricula is rooted in a long history of agency and transaction-cost perspectives, which create an "organization-centered worldview" (Giacalone \& Thompson, 2006). Much has changed since to where MBA curriculum are constantly being revised to ensure relevance. MBA curriculum now focus strongly on developing the soft skills that employers expect in effective managers and leaders.

A report published by AACSB in 2013 explained quite effectively the perspectives and concerns of MBA faculty in the U.S. The report cited the rise of substitutes, including high quality MBA programs outside the U.S., research lacking relevance, a need for broader research approaches, and some critical management and leadership skills not taught effectively (Datarand \& Garvin, 2013).

Furthermore, recent research suggests that courses designed to inculcate human capital competencies are wholly underrepresented in MBA curricula e.g. (R. Rubin \& Dierdorff, 2011.). Scholars have attributed culpability in various directions, collectively suggesting a broad devaluing of management education from one or more stakeholders including recruiters, business school policy makers, faculty members, and students (R. S. Rubin \& Dierdorff, 2011). As a result of some of the afore-mentioned critiques and ensuring curriculum and assurances of learning outcomes' relevance, AACSB revised its standards to ensure they:

- Drive innovation in business schools to create and sustain value for students, employers, and the communities they serve.

- Go beyond quality and ensure that business schools also have an impact through both scholarly education and the creation of new knowledge. 
- Require significant engagement between faculty, students, and business professionals, fostering meaningful intersections to create and share knowledge that is both scholarly and relevant to practice (AACSB, 2013).

\section{Employers Expectations and Perspectives on the Effectiveness of MBA Programs}

MBA programs are highly valued by companies and managers because they are perceived as a space to enhance managers' business practices and prepare them to deal with the environment of uncertainty and rapid changes in the current socioeconomic context (Vazquez \& Ruas, 2012). Given the value placed on MBA programs, business schools have been under fire for their alleged inefficacy in developing students' managerial skills in MBA programs. (Varela, Burke, \& Michel, 2013). In assessing the expectation of MBA programs, we focus on the following skill sets given the frequency of being cited in various studies.

Leadership skills. Many business schools have been seeking to instill a stronger focus on leadership skills in their MBA programs. Leadership skills include both the "hard skills" (such as accounting, finance, and strategy) and the "soft skills" (such as leadership, team work, and ethics) (Ingols \& Shapiro, 2014).

Practical Experience. Students should take on as many practical opportunities as possible and participate in clubs and charities to try their hand at managing people. Capstone classes should provide practical business relevance as a means for students to transition to the business world (Inamdar \& Roldan, 2013).

International Experience. Business schools worldwide are increasingly internationalizing their curriculum to address globalization, accreditation expectations, and other trends. One way to internationalize is through study-abroad courses, providing students with invaluable experiential learning overseas (Hurst, Lam, \& Khare, 2013).

Worldly View. The world is shrinking, which means MBAs have to be knowledgeable about countries and cultures that may not be on their radar. Randolph (2011) reiterated the need to develop global business capabilities in MBAs is clear and growing, and faculty must create efficient and effective processes for developing these capabilities.

Adaptability. Learning to try on different hats and to migrate from your comfort zone can go a long way toward impressing the boss of a new venture or a large multinational. An entrepreneurial attitude is also important at Philips. "We want people who are going to run their functional space as if it's their own (Meglio, 2013 ).

There is little doubt of employers' commitment and interest in hiring MBA graduates. A recent survey by Graduate Management Admission Council (2014) as cited in (Hellmich, 2014), highlighted people who just earned their MBA have another reason to celebrate in that $86 \%$ of U.S. companies with business school recruiters plan to hire MBA graduates in 2014, up from $81 \%$ in 2013 and $51 \%$ in 2009 during the economic downturn. The survey included business school recruiters for 565 employers, including 36 Fortune 100 companies. According to the survey, the projected median U.S. base salary for MBAs in 2014 is $\$ 95,000$, similar to last year. That compares with a median annual salary of $\$ 50,000$ for bachelor's degree recipients.

\section{Discussions, Recommendations, \& Conclusions}

Many studies have undertaken endeavors to assess the effectiveness of various elements of higher education. The MBA degree has been shown to enable students to (a) obtain jobs, (b) earn higher salaries, and (c) succeed in subsequent job performance (Iacobucci, 2013). Attaching the MBA to your name can affect your hiring chances, your networking abilities, and your innovation skills (Mondalek \& Rogers, 2013).

While there are significant challenges and critiques of the MBA and causes for concern, there is no doubt that MBAs have to be directly associated with results of managers' and company performance (Vazquez \& Ruas, 2012).

Business schools worldwide are continuously changing their curriculum to ensure relevance. This includes increasingly internationalizing their curriculum to address globalization, accreditation expectations, and other trends. Hurst et al. (2013) suggested study-abroad courses as one way to internationalize MBA students with invaluable experiential learning overseas.

Graduate business education needs to deal not just with business but also with leadership in a more complex world. Tomorrow's market will expect leaders to understand the relationship between industry, economy and community, because the world now expects more responsible leadership and sustainable commerce. Tomorrow's fast-track leaders will be less inclined to set aside their jobs for a traditional MBA (Smith, 2011). Furthermore,

- The market doesn't want more of the same.

- Students want more from a graduate degree than the traditional MBA offers 
- Traditional program delivery will not meet the needs of the students of the next decade.

- Leadership and managerial skill assessment have to be built into the core curriculum.

Without "doing" skills, "knowing" is of little value, but "doing" skills will be ineffective and direction-less without the self-awareness and reflection on values and beliefs that come from developing "being" (Datarand \& Garvin, 2013). Hopefully, through rigorous theories, practical experiences, and deep reflections, MBA graduates can excel and create significant value in organizations. It will take strong partnerships among students, faculty, and employers to ensure curriculum, experiences, and expectations are all in sync.

\section{References}

Bedwell, W. L., Fiore, S. M., \& Salas, E. (2014). Developing the Future Workforce: An Approach for Integrating Interpersonal Skills Into the MBA Classroom. Academy of Management Learning \& Education, 13(2), 171-186. http://dx.doi.org/10.5465/amle.2011.0138

Blackburn, G. (2011). Which Master of Business Administration (MBA)? Factors influencing prospective students' choice of MBA programme - an empirical study. Journal of Higher Education Policy \& Management, 33(5), 473-483. http://dx.doi.org/10.1080/1360080X.2011.605222

Constable, J., \& McCormick, R. (1987). The Making of British Managers. CBI.

Datar, S. M., Garvin, D. A., \& Cullen, P. G. (2010). Rethinking the MBA: Business education at a crossroads. Boston, MA: Harvard Business Press.

Datarand, S. M., \& Garvin, D. A. (2013). The Changing MBA Marketplace and Approaches to MBA Curriculum Redesign. Harvard Business School: AACSB International.

Giacalone, R. A., \& Thompson, K. R. (2006). Business ethics and social responsibility education: Shifting the worldview. Academy of Management Learning \& Education, 5(3), 266-277.

Goleman, D. (1998). Working with emotional intelligence. Bantam Press.

Hann, C. (2014). TO MBA or NOT TO MBA. Entrepreneur, 42(10), 79-83.

Hellmich, N. (2014). More companies hiring new MBAs. USA Today.

Hurst, D., Lam, H., \& Khare, A. (2013). Internationalizing MBA Curriculum Through Overseas Experiential Learning Courses: Insights on Strategies, Design, Implementation, and Outcomes. Journal of International Business Education, 8, 49-74.

Iacobucci, D. (2013). A Psychometric Assessment of the Businessweek, U.S. News \& World Report, and Financial Times Rankings of Business Schools' MBA Programs. Journal of Marketing Education, 35(3), $204-219$. http://dx.doi.org/10.1177/0273475313491576

Inamdar, S. N., \& Roldan, M. (2013). The MBA Capstone Course: Building Theoretical, Practical, Applied, and Reflective Skills. Journal of Management Education, 37(6), 747-770. http://dx.doi.org/10.1177/1052562912474895

Ingols, C., \& Shapiro, M. (2014). Concrete Steps for Assessing the "Soft Skills" in an MBA Program. Journal of Management Education, 38(3), 412-435. http://dx.doi.org/10.1177/1052562913489029

Lundstrom, W. J. (2011). MBA Attitudes Toward Business: What We Don't Know Can Hurt Us or Help Us. Journal of Education for Business, 86(3), 178-185. http://dx.doi.org/10.1080/08832323.2010.496301

Meglio, F. (2013 ). Some MBAs Aren't Job-Ready, Employers Say. Businessweek, February.

Mondalek, A., \& Rogers, A. (2013). Here's What Recruiters And CEOs Really Think About The Value Of An MBA. Business Insider, July.

Neuman, G. A., \& Wright, J. (1999). Team effectiveness: Beyond skills and cognitive ability. Journal of Applied Psychology, 84, 376-389.

Porter, L., \& McKibbin, L. (1988). Management Education and Development: Drift or Thrust into the 21st Century? New York: : McGraw-Hill.

Randolph, W. A. (2011). Developing Global Business Capabilities in MBA Students. Journal of Management Inquiry, 20(3), 223-240. http://dx.doi.org/10.1177/1056492611401027 
Rapert, M. I., Smith, S., Velliquette, A., \& Garretson, J. A. (2004). The Meaning of Quality: Expectations of Students in Pursuit of an MBA. Journal of Education for Business, 80(1), 17-24.

Rubin, R., \& Dierdorff, E. C. (2011.). On the road to Abilene: Time to manage agreement about MBA curricular relevance. Academy of Management Learning and Education, 10, 148-161.

Rubin, R. S., \& Dierdorff, E. C. (2011). On the Road to Abilene: Time to Manage Agreement About MBA Curricular Relevance. Academy of Management Learning \& Education, 10(1), 148-161. http://dx.doi.org/10.5465/AMLE.2011.59513280

Sculley, J. (1988). A perspective on the future: What business needs from higher education. . Change, 20(41).

Smith, K. E. N. (2011). The MBA's Last Gasp. Canadian Business, 84(3), 50-51.

Sulaiman, A., \& Mohezar, S. (2009). Quality in an MBA programme: students' perceptions. International Journal of Management Education (Oxford Brookes University), 7(2), 1-8. http://dx.doi.org/10.3794/ijme.72.204

The-Aspen-Institute. (2008). Where will They lead? MBA student attitudes about business \& society. New York, NY: Aspen Institute.

Varela, O., Burke, M., \& Michel, N. (2013). The development of managerial skills in MBA programs A reconsideration of learning goals and assessment procedures. Journal of Management Development, 32(4), 435-452. http://dx.doi.org/10.1108/02621711311326400

Vazquez, A. C. S., \& Ruas, R. L. (2012). Executive MBA Programs: What Do Students Perceive as Value for their Practices? (English). RAC - Revista de Administração Contemporânea, 16(2), 308-326. 